\title{
БИОДЕМОГРАФИЧЕСКИЕ АСПЕКТЫ АДАПТАЦИИ КЕРЧЕНСКОЙ ДИАСПОРЫ ИТАЛЬЯНЦЕВ*
}

\begin{abstract}
После краткого введения об истории возникновения и формирования диаспоры «итальянцев Крыма», в статье описаны результаты комплексного социиалього и биодемографического анализа, проведенного среди современньх представителей изучаемой группь, на основании разработанной нами программы анкетирования.

Представленные данные, собранные в ходе экспедищий в Крым и в Италию в 2016-2019 г2., обнародуются впервые. Современные итальянцы Крыма являются потомками итальянских мигрантов, прибывших в черноморско-азовский регион, в частности на Крымский полуостров с Апеннинского полуострова, разными миграционными потоками, с конца ХVIII века и до начала ХХ века.
\end{abstract}

Ключевые слова: биодемография, миграционные потоки, мигранты, исторический очерк, полевые исследования, Крымские итальянцы, Керчь, Апеннинский полуостров, Италия, Крым

\section{Введение}

Керчь - южный многонациональный город РФ, численность которого в 2019 году составила 151025 человек. В настоящее время в Керчи, а также в других городах Крымского полуострова проживает группа численностью около 200 индивидов итальянского происхождения. Они являются потомками итальянских мигрантов, прибывших из Апеннинского полуострова в города Черноморско-Азовского бассейна, начиная с конца XVIII и до начала XX вв. На основании документов и свидетельств из

Дзини Стефания - соискатель ученой степени к.и.н. Института этнологии и антропологии РАН (Москва, Ленинский пр. 32А). Председатель комиссии этнографии, антропологии и археологии МГО РГО (Новая площадь, д. 10, стр. 2). Эл. почта: stefania.zini@mail.ru. Zini, Stefania - Institute of Ethnology and Anthropology of the Russian Academy of Sciences (Moskva, Leninskii pr. 32A), Russian Geographic Society (Novaya ploshchad', 10(2)). E-mail: stefania.zini@mail.ru

Спицына Наиля Хаджиевна - д.и.н., ведущий научный сотрудник Центра физической антропологии, Института этнологии и антропологии РАН (Москва, Ленинский пр. 32-a). Эл. почта: nailya47@ mail.ru. Spitsyna, Nailya H. - Institute of Ethnology and Anthropology, RAS (Moscow, Leninsky Pr. 32a).E-mail: nailya47@mail.ru

Хохлов Никита Викторович - научный сотрудник Института этнологии и антропологии РАН (Москва, Ленинский пр. 32А). Ученый секретарь комиссии этнографии, антропологии и археологии МГО РГО (Новая площадь, д. 10, стр. 2). Эл. почта: ethno@yandex.ru. Khokhlov, Nikita V. - Institute of Ethnology and Anthropology of the Russian Academy of Sciences (Moskva, Leninskii pr. 32A), Russian Geographic Society (Novaya ploshchad', 10(2)). E-mail: ethno@yandex.ru

Статья публикуется в соответствии с планом научно-исследовательских работ Института этнологии и антропологии РАН 
российских и итальянских архивов ${ }^{1}$ мы воссоздали географию и хронологию трех основных миграционных потоков итальянцев ${ }^{2}$ в Черноморско-азовский регион России.

Во время первой миграции конца XVIII - первой половины XIX вв. большинство итальянских переселенцев поселились в основанном в 1794 году городе Одесса. Этот первый поток условно назван «одесской миграцией». Позже, миграционные пути итальянцев сместились на восток и мигранты появились в разных городах Крымского полуострова. В течение первого и второго десятилетий XIX в., выходцы из Италии, проживающие в Одессе, а также итальянские семьи, прибывшие непосредственно с Апеннинского полуострова, расселялись в Феодосии. Этот комплекс международных и локальных миграций представляет собой «феодосийскую миграцию».

Начиная с 1820-1830-х годов и до конца XIX века новым, предпочтительным местом переселения итальянских мигрантов становится город Керчь. Расположенный вдоль берега Керченского пролива, на стыке двух морей, Черного и Азовского, в разные исторические периоды Керчь являлся ключевой географической точкой между Западом и Востоком и стратегическим морским проходом к важным морским торговым узлам Азовского моря, таким как Таганрог, Мариуполь, Бердянск. В эти города итальянцы начали мигрировать со второй половины XIX в. Третий поток итальянцев в регион назван «керченско-азовской миграцией».

Изучение архивных источников позволило проследить пути миграции жителей Апеннинского полуострова в Крым и в разные города Черноморско-Азовского бассейна. Анализ исторических материалов, также дал объективные ответы на вопросы: кем были итальянские мигранты, что вынудило их покинуть родину и совершить трудное, в то время очень рискованное путешествие, чтобы переселиться в этот далекий регион. Среди мигрантов были представители итальянского культурного мира, как с севера, так и с юга Апеннинского полуострова. Однако, подавляющее большинство переселенцев составляли люди, связанные с морем, состоятельные судовладельцы и торговцы, мигрировавшие из севера итальянского полуострова, в основном из регионов современной Лигурии и Пьемонта.

Итальянские мореходцы подошли к вопросу миграции в Черноморско-азовский регион весьма прагматично и воспользовались возможностью расширения своего коммерческого влияния на Востоке и обогащения, в связи с удачно сложившейся исторической ситуацией конца XVIII - начале XIX веков. Когда миграционные процессы с Апеннинского полуострова только начались, в Европе люди страдали от нехватки основных продуктов, таких как мука и хлеб, вызванной политикой и грабительскими планами Бонапарта. А на востоке располагались богатые земли Российской Империи, где иностранные колонисты приветствовались.

${ }^{1}$ Государственный архив Республики Крым, г. Симферополь; Государственный архив Саратовской области ГАСО - г. Саратов; Российский государственный военный архив РГВА г. Москва; Российский государственный архив древних актов РГАДА - г. Москва; Российская государственная библиотека - г. Москва; Центральный государственный архив - г. Санкт-Петербург; Государственный архив г. Генуя; Ватиканский секретный архив - г. Рим; личные архивы крымских итальянцев, Джулии Джаккетти-Бойко (г. Керчь) и Петра Пергало (г. Санкт-Петербург) и других представителей группы.

${ }^{2}$ Когда речь идет о событиях, предшествующих объединения Италии 1861 года, в тексте используем словом Италия, в качестве совокупного, условного названия всех государств Апеннинского полуострова. Также называем итальянцами всех жителей и мигрантов из Апеннинского полуострова, вне зависимости от государств происхождения. 
В России, вторая половина XVIII века была временем правления Екатерины Великой (1762-1796), убежденной, что массовый приток иностранных мигрантов в Россию может способствовать быстрому освоению и развитию малонаселенных территорий Империи. Вместе с колонистами появлялась не только недостающая рабочая сила, но и новые, неизвестные в Империи технологии, привезенные мигрантами из-за границы. (Писаревский 2011: 96-106, 117). Екатерина II уделяла особое внимание регионам Черного и Азовского морей. Они были присоединены к Российской Империи в 1774 году после подписания в конце русско-турецкой войны выигрышного для России Кючу́к-Кайнарджи́йского мирного договора, с включением в 1783 году Крымского ханства (т.е. Крымского полуострова) в состав Российской империи. Она понимала, насколько важным было заселение вновь приобретенных земель народами, верными Российской Империи. Необходимо было также противостоять потенциальным угрозам со стороны Османской Империи, веками доминировавшей в этом регионе и не готовой смиряться с потерей гегемонии на важнейших геополитических и стратегических территориях.

У Екатерины Великой был конкретный, долгосрочный план создания в регионе христианской империи со столицей в Константинополе (Gardini, Sinigaglia, Rebora 2003-2004), чтобы основательно победить османов. Для осуществления «греческого проекта» максимально способствовали миграциям христиан, предлагая колонистам исключительные привилегии и бесплатные земли. Будучи лидером Русской Православной Церкви, она приглашала, в первую очередь, православные народы - русских из других регионов и православных иностранцев, греков, арнаутов, армян, болгар.

Вскоре после начала процессов колонизации южных территорий Империи, в Крым и в Черноморско-Азовский регион были также привлечены мигранты христианского (католического) вероисповедания. С этого момента, начались миграции жителей Апеннинского полуострова, которым Крымский полуостров и берега Черного и Азовского морей были известны с давних времен. Нельзя исключать также, что итальянских мигрантов влекло в эти регионы желание вернуть земли, принадлежавшие Генуэзской республике в средние века и позже завоеванные османами, такая тихая экспансия с далеко идущими планами геополитического характера. Они могли надеяться на повторение коммерческих успехов своих средневековых предков. Может быть, это и простое совпадение, но в XIX веке, интерес к истории генуэзской колонизации и к генуэзскому наследию Черноморско-азовского региона заметно вырос среди итальянских историков.

Таким образом, с конца XVIII в. и протяжении всего XIX в. - с перерывами в годы войны - сотни итальянцев переселились в разные города Черноморско-Азовского бассейна. Некоторые обосновались в этих регионах навсегда, но для множества мореходцев, шкиперов, торговцев, суда которых регулярно курсировали по Средиземному, Черному и Азовскому морям, местные портовые города представляли собой всего лишь место временного проживания. Тем не менее, независимо от того, стали ли новой родиной или были временным пристанищем, города Черноморско-Азовского региона и полуостров Крым, на протяжении более столетия приносили многим итальянцам большой материальный доход.

Во второй половине XIX века, после окончания второй Крымской войны (18531856) и с основанием Королевства Италии в 1861 г., фиксируется новая волна миграций итальянцев, которая продолжается вплоть до конца XIX века. Город Керчь стал 
главным местом притяжения для новых мигрантов. В отличие от всех предыдущих, этот новый миграционный поток состоял из итальянцев (многих гарибальдийцев), покинувших страну, главным образом, по политическим причинам, связанным с происходящими историческими изменениями на родине. Для этих итальянцев коммерческая составляющая миграции была также важной, но направленной в первую очередь, на образование капиталов, необходимых для поддержания и развития их политических планов.

Новые итальянские политэмигранты появляются в регионе и в годы Октябрьской Революции, и также в советское время, но здесь речь здесь идет о единичных случаях. В советский период, наоборот, регистрируется большой отток итальянцев. Многие из них возвращаются в Италию, так как советская общественно-политическая система не давала возможности заниматься свободной индивидуальной трудовой деятельностью. Тех, кто остался, в 1942 году во время Великой Отечественной войны, выслали из Крыма в Казахстан. В конце войны, часть из них обосновалась на местах ссылки, или переехали в города СССР. Некоторые смогли вернуться в Италию. Люди, которые утратили все связи с исторической родиной, вернулись в Крым, в основном в Керчь, город в котором перед войной сосредоточилось большинство потомков итальянцев (рис.1).
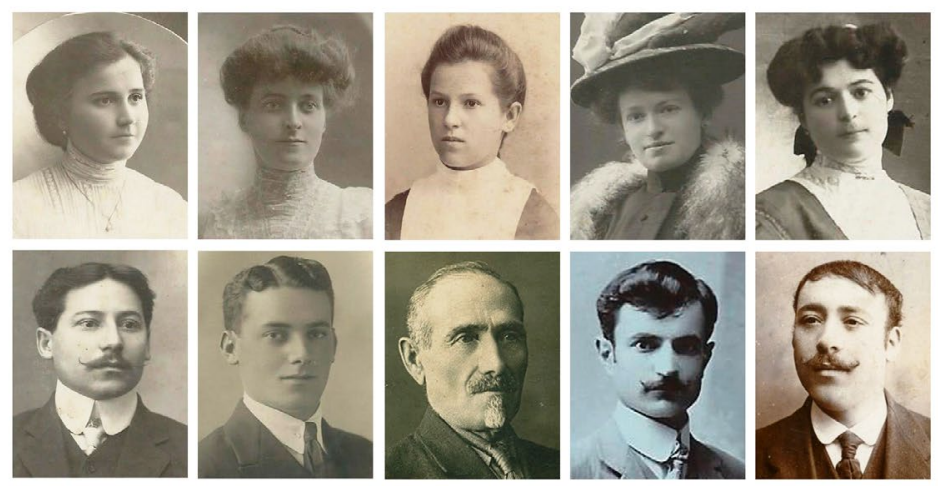

XIX век
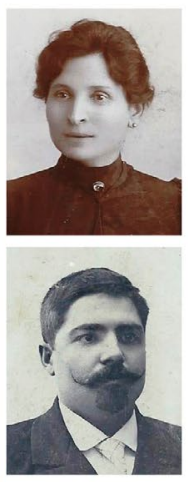

XX век
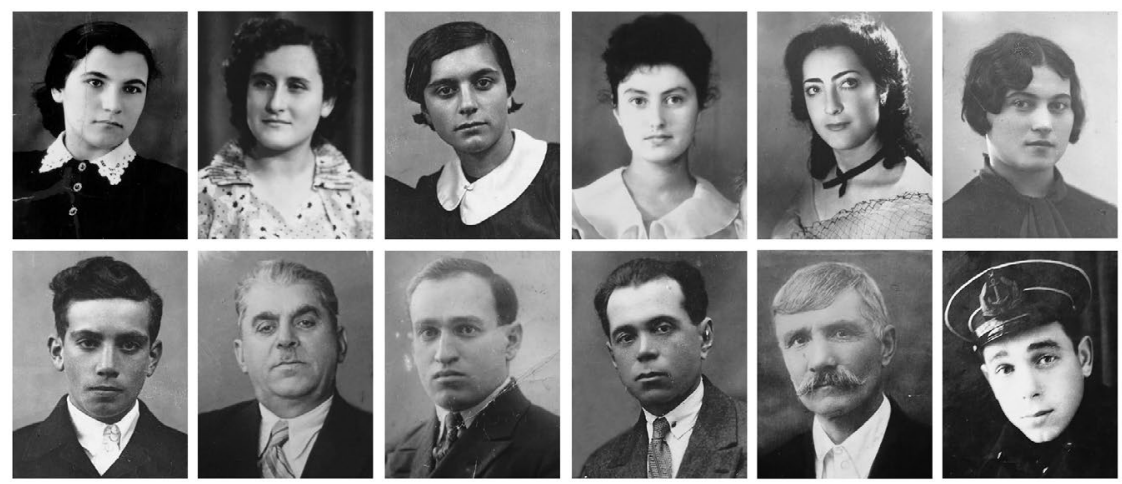

Рис. 1. Фотопортреть итальянцев Крыма ХІХ и ХХ вв. Фотографии из семейньхх архивов итальянщев Крыма. Фотоматериаль, собранные С. Дзини и Н. Хохловым в ходе экспедиций в Крым и в Италию в 2016-2020 г2. 


\section{Итальянцы Крыма сегодня}

Современные итальянцы Крыма являются, в основном, потомками итальянских мигрантов, прибывших на Крымский полуостров с самыми поздними миграционными потоками. Тем не менее, среди нынешних представителей группы, находим также фамилии, принадлежащие, по данным из источников, жителям Апеннинского Полуострова, мигрировавших в Одессу, в Феодосию, в Керчь и в другие города Черноморского и Азовского бассейнов в более ранние периоды (Дзини, Хохлов 2016-2019).

Имеются следующие официальные документы:

1. В итогах переписи населения в Крымского Федерального Округа, состоявшегося при участии федеральных властей Российской Федерации, с 14 по 25 октября 2014 г., итальянцы представлены как отдельный народ, среди 133 перечисленных национальностей, в разделе «Распределение населения по национальности и владению русским языком». Общее число лиц итальянской национальности в Крымском Федеральном Округе - 77 чел. обоих полов (70 в Республике Крым и 7 в г. Севастополь). Из них, владеют русским языком - 72 чел. (66 в Республике Крым и 6 в г. Севастополь).

2. Из общего количества лиц, указавших свою национальную принадлежность 2197564 чел., 2184518 чел. - то есть 99,4\% - владеют русским языком. Итальянцы составляют $0,0035 \%$ из общего количества, 0,0032\% из лиц, владеющих русским языком $^{1}$ (Итоги переписи населения в Крымского Федерального Округа 2014: 125, 129).

3. Официальный статус группы: указом Президента РФ от 12 сентября 2015 г. № 458 «О внесение изменений в Указ Президента РФ от 21 апреля 2014 г. № 268 «О мерах по реабилитации армянского, болгарского, греческого, крымско-татарского и немецкого народов государственной поддержке их возрождения и развития», (http:// kremlin.ru/acts/bank/38356) итальянцы де-юре включены в список малочисленных народов Крыма.

Сбор социальной и биодемографической информации в Керченской диаспоре был проведен нами в ходе экспедиций в 2016-2019 годов. Работа с архивными материалами позволила реконструировать сложную историю возникновения Керченской группы. Проведение комплексного социального и биодемографического исследования населения дало возможность составления общей демографической и социокуль-

\footnotetext{
${ }^{1}$ В других разделах итогов переписи, итальянцев, как отдельная национальность, не находим.

В разделе об изменении национального состава населения, среди 23 перечисленных наиболее многочисленных и иных национальностей Крыма, итальянцев нет. Данные указаны за 1989, 2001 и 2014 гг.

Итальянцы вошли в суммарную группу крымчан, которые дали «другие ответы о своей национальной принадлежности, не перечисленные выше». Речь идет о 13.196 чел. обоих полов в 1989 г., когда общее количество населения в Крымском Федеральном Округе было 2430495 чел. обоих полов, 13699 из 2. 401209 жителей обоих полов в 2001 г. и 14319 из 2284769 чел в 2014 г. (c. 108).
}

Итальянцев также не находим, как отдельная национальность, в перечне наиболее многочисленных национальностей. Итальянцы вошли в группу «другие национальности», куда совокупно включены представители всех остальных национальностей, отличных от тех, указанных в списке.

Суммарный процент представителей «других национальностей» составляет от минимального $0,6 \%$ в Терновском муниципальном округе до максимального $2,3 \%$ в городском округе Симферополь.

В городском округе Керчь составляет 1,3\%. (с. 135-141). 
турной характеристики современных крымских итальянцев. Собранные материалы и результаты, полученные после обработки данных, помогают ответить на основные взаимосвязанные вопросы:

- какова на сегодняшний день численность и динамика формирования Керченской диаспоры, по каким признакам и критериям можно считаться членом группы;

- попытаться оценить динамику произошедших адаптивных процессов среди потомков итальянских мигрантов.

Известно, что представители изучаемой группы проживают не только в Крыму. Несколько семьей потомков итальянских мигрантов живут в разных городах Российской Федерации, Казахстана, а также в других регионах и странах ${ }^{1}$, где представители ушедших поколений поселились после депортации 1942 года. Мы решили исследовать только тех, кто сегодня проживает в Крыму, чьи предки, либо не были выселены из Крыма, или после войны, вернулись из ссылки в Крым. Также разыскали и включили в список исследуемых, итальянцев, родившихся в Крыму, вернувшихся на исконную родину и, проживающих в настоящее время в городах Италии Триесте, Турине, Милане, Генуе.

Данное решение мотивировалось желанием получения максимально объективной картины процесса формирования социальной и биодемографической структуры итальянской общины.

В процессе анкетирования были собраны сведения об уровне образовании, роде деятельности, вероисповедании респондента, членов его семьи и родственников. Учитывалось знание итальянского языка, наличие или отсутствие чувства принадлежности к итальянскому этносу, у опрошенного, а также членов семьи и близких родственников. С целью определения степени эндогамии/экзогамии и прослеживания процесса метисации в группе, были зафиксированы знания и воспоминания, опрощенных о предках по отцовской и материнской линии, до пятого поколения (прабабушек и прадедушек), а именно: их национальность по паспорту и по происхождению, место и дата рождения, основное место жительства. Собирались любые дополнительные сведения о миграции старших поколений итальянцев из Апеннинского полуострова в Черноморско-Азовский регион, дальнейшей их судьбе. Учитывались также воспоминания о депортированных во время Великой Отечественной Войны, о возвратившихся в Италию (рис. 2).

Всего исследовано 111 индивидов итальянского происхождения - 64 женского и 47 мужского пола. Из них, родилось и постоянно проживает в Крыму, преимущественно в г. Керчь 101 человек (59 женского и 42 мужского пола), что соответствует $90,99 \%$ от общего количества испытуемых. Остальные $10(0,01 \%)-5$ женщин и 5 мужчин - родились в Керчи и в настоящее время проживают в Италии. Прежде чем составить характеристику диаспоры по данным проведенного исследования, необходимо подчеркнуть, что количество (101 чел.) опрошенных, проживающих в Керчи превышает число жителей Крымского Федерального Округа, которые в ходе переписи населения 2014 г. признали себя лицами итальянской национальности (77 чел.).

\footnotetext{
${ }^{1}$ В Российской Федерации - Москва, Санкт-Петербург, Калининград, Тула, Саратов, Самара, Ростов-на-Дону, Краснодар, Новороссийск, Таганрог, Абакан, Челябинск, Владивосток; в Украине - Киев, Одесса, Запорожье, Мариуполь, Бердянск; в Казахстане - Нур-Султан, Алма-Ата; в Узбекистане - Ташкент; в Армении - Ереван.
} 


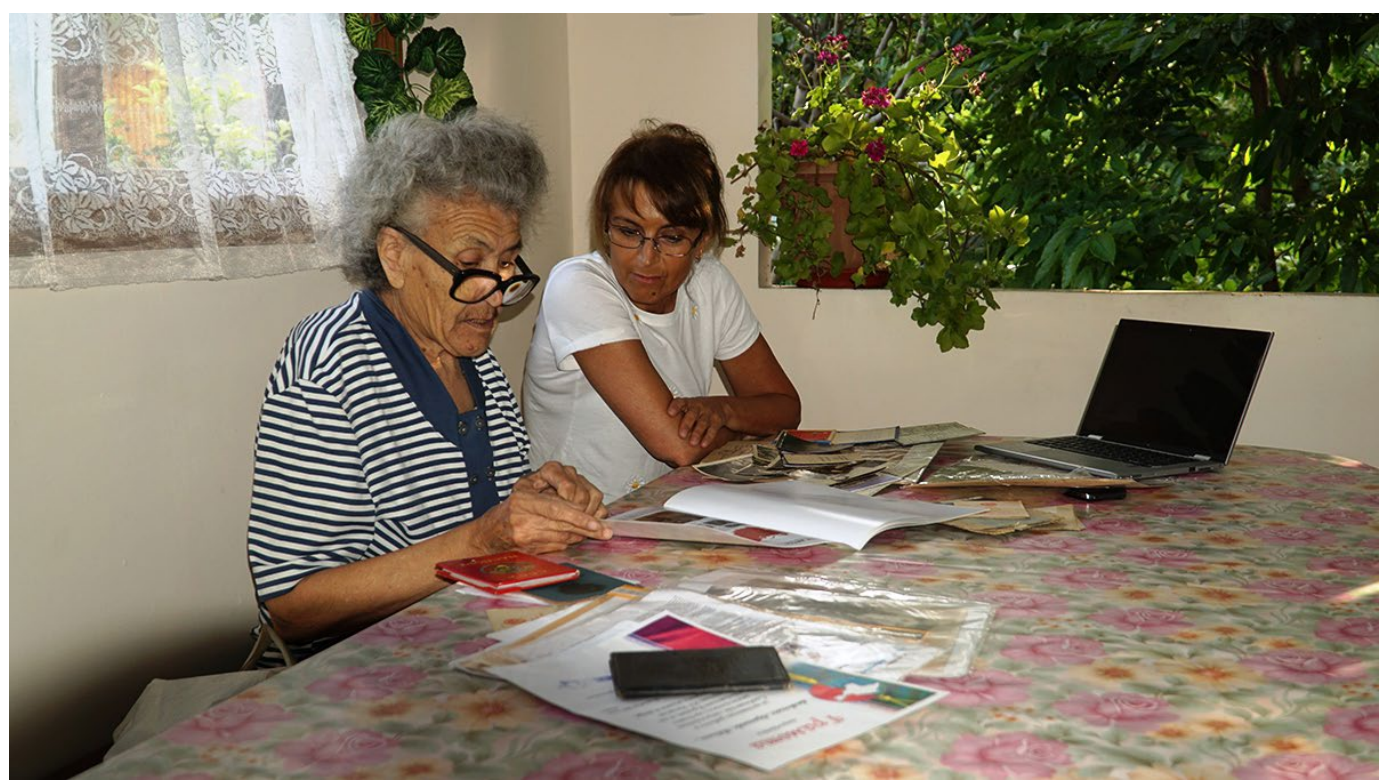

Рис. 2. Крым. Керчь. Стефания Дзини и Джсованнелла Фабиано, одна из старших представителей диаспоры итальянцев Крыма. Автор фотографии Никита Хохлов.

При проведении исследования мы руководствовались сведениями, переданными сообществом итальянцев Крыма ЧЕРКИО ${ }^{1}$, по которым численность лиц итальянской национальности, проживающих на полуострове Крым, составляет примерно 200 человек. Исследуемая нами выборка респондентов составила 50,5\% от общего числа. Следует иметь в виду, что любые данные, о численностях населения относятся к конкретному времени и постоянно изменяются во времени и пространстве, поскольку зависят от процесса естественного движения населения и целого комплекса причин биологического и социального характера. В зависимости от социально-культурной и политической обстановки может меняться также признание принадлежности к итальянской диаспоре, что неудивительно в семьях родственники, которых пережили репрессии и депортацию². Были также единичные случаи, когда лица, называющие себя итальянцами Крыма, не являлись таковыми.

\section{Распределение итальянцев Крыма по полу и возрасту}

Распределение изучаемой группы по полу и возрасту отражено на рис. 3. В левой части половозрастной пирамиды представлены мужчины, в правой -женщины.

${ }^{1}$ Итальянская Ассоциация «ЧЕРКИО» открылась в Керчи в 2008 году. Слово «черкио» с итальянского переводится, как «круг». Черкио - это также старое название г. Керчь. Кроме того, итальянская аббревиатура C.E.R.K.I.O. обозначает Comunità degli Emigrati in Regione di Crimea - Italiani di origine, в переводе на русском - Сообщество потомков, эмигрировавших в Крым, итальянцев по происхождению (Джаккетти-Бойко 2016:16)

2 Данные, предоставленные нам Итальянской Ассоциацией «ЧЕРКИО», о количестве представителей группы, проживающих в других городах и странах (в Италии, в том числе) являются еще менее точными и более фрагментарными. Как правила, речь идет только о семьях или отдельных индивидах, о существовании которых еще известно по одной единственной причине: они состоят в родственных связях с керченскими итальянцами, проживающих в Крыму. Связь с потомками итальянских мигрантов, не имеющих сегодня родных в Крыму, почти полностью утеряна. 
Мужчины - 0-10 лет - 1 чел.; 11-20 лет - 4 чел.; 21-30 лет - 7 чел.; 31-40 лет 7 чел.; 41-50 лет - 9 чел.; 51-60 лет - 4 чел.; 61-70 лет - 5 чел.; 71-80 лет - 7 чел.; 81-90 лет - 2 чел.; 91-100 лет - 1 чел.

Женщины - 0-10 лет - 1 чел.; 11-20 лет - 6 чел.; 21-30 лет - 7 чел.; 31-40 лет 3 чел.; 41-50 лет - 10 чел.; 51-60 лет - 10 чел.; 61-70 лет - 10 чел.; 71-80 лет 10 чел.; 81-90 лет - 7 чел.; 91-100 лет - 0 чел.

Обращает на себя внимание резко деформированная форма половозрастной пирамиды формы урны с резко суженным основанием за счет малого числа младших возрастных групп. Возраст самого старшего и самого младшего представителя мужского пола - 95 лет и 6 лет, женского пола - 87 и 9 лет.

Возрастная пирамида итальянцев Крыма на 2017-2019 гг.

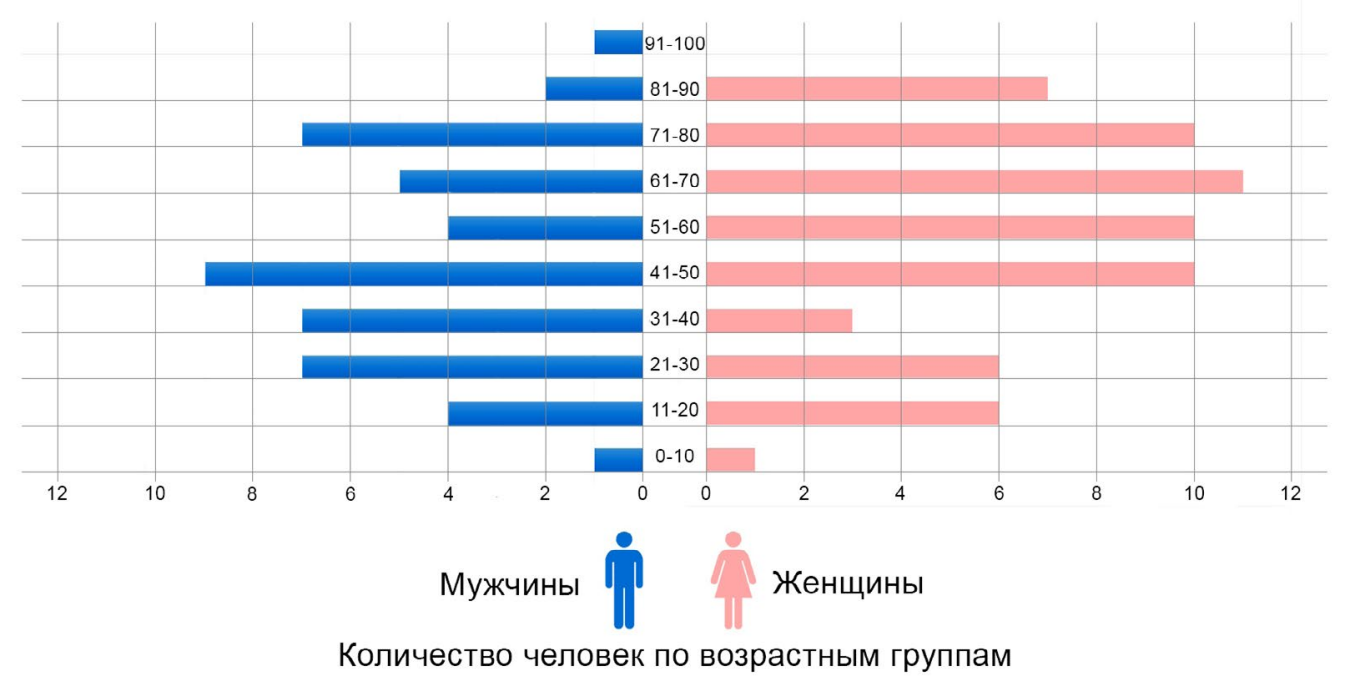

Рис. 3. Возрастная пирамида итальянцев Крыма на 2017-2019 годы.

\section{Гражданство представителей группы}

Никто из представителей итальянской диаспоры, проживающих в Керчи, не имеет итальянского гражданства. Их предки приняли подданство Российской Империи, позднее стали гражданами Советского Союза и отказались от итальянского подданства. Итальянцы Крыма были советскими гражданами и/или, после распада СССР гражданами Украины, в настоящее время они все приняли Российское гражданство, сохраняя в некоторых случаях украинский паспорт. Важно отметить, что только в единичных случаях (4 из 101), представители группы сохранили итальянскую национальную принадлежность в графе «национальность», которая существовала с 1974 года в советском паспорте и в российском, пока она не была отменена в 1990 -е годы ${ }^{1}$.

\footnotetext{
${ }^{1}$ На сегодняшний день, по желанию родителей, в свидетельство о рождении может быть внесена запись о национальности родителей (одного из родителей) - Федеральный закон «Об актах гражданского состояния» от 15.11.1997 N 143-Ф3 ст. 23 (ред. от 03.07.2019). Среди испытуемых, сохранение итальянской национальности в свидетельствах о рождениях не зафиксировано.
} 
В советское время, большинство из представителей группы предпочитало скрывать свое итальянское происхождение, поменяв итальянскую национальность на русскую, дабы избежать возможных неприятностей с властями. Для тех немногочисленных людей, чьи родственники не побоялись открыто заявить об исконной национальности, данный факт является предметом особой гордости. На основании этой принципиальной отличительной черты, по отношению к остальным представителям группы, они считают справедливым называть себя единственными чистокровными итальянцами и настоящими итальянцами Крыма. Это является одной из причин имеющихся внутригрупповых противоречий и конфликтов. Группа, внешне сплоченная и дружная, в действительности, разделена на соперничающие группировки, каждая из которых периодически пытается завоевывать лидерство в общине.

Среди 10 опрошенных, проживающих в Италии, все имеют итальянское гражданство, кроме 2 женщин, которые являются гражданами Российской Федерации и находятся в Италии на разных правовых-миграционных основах.

\section{Вероисповедание в группе}

Из 101 испытуемых, проживающих в Крыму, 12 человек считают себя католиками (5 из них женского и 7 мужского пола), 69 - православными (37 женщин и 32 мужчин). 11 представителей группы (10 человек женского и 1 мужского пола) ощущают себя одновременно католиками и православными. Их двойное вероисповедание выражается в равном соблюдении календарных православных и католических церковных праздников, а также в посещении православной церкви или католического костела. Все современные итальянцы Крыма крещены в православной церкви, кроме одной женщины, которую крестили дважды - официально в православии, а по воле бабушки, дома по католическому обряду. В группе также имеются 4 атеиста (1 женщина и 3 мужчины), и 3 женщины, верующие в Бога, но не в церковь, как институт, 1 представитель женского пола, верующий в силы природы и 1 протестант.

Среди 10 представителей группы, проживающих в Италии, 6 человек католики, 2 православные и 2 считают себя одновременно католиками и православными.

\section{Чувство этнической принадлежности}

Опосредованно судить о фактическом количестве итальянцев Крыма на сегодняшний день, поможет ответ на вопрос о присутствии или отсутствии, у потомков итальянских мигрантов, чувства этнической принадлежности к итальянскому народу. «Считает ли и ощущает ли испытуемый, что он итальянец?», был одним из вопросов предлагаемой анкеты. Из 101 испытуемых, проживающих в Крыму, утвердительно ответили 73 человек (44 женщин и 29 мужчин), отрицательно - 18 представителей группы (10 женского и 8 мужского пола). 10 человек (6 женщин и 4 мужчины) не знали, как ответить на данный вопрос, объясняя, что не задумываются, или не хотят об этом думать.

В случае положительного ответа на вопрос, мы просили опрошенных описывать, в чем выражается и, как проявляется их чувство принадлежности к группе этнических итальянцев. Оказалось, что в большинстве случаев, оно связано с вкусовыми ощущениями и пристрастиями. Любовь к типичным итальянских блюдам - “пасте” (общее итальянское название макарон всех видов и форм), пицце, сыру “моццарелла” или “пармиджиано” - или к характерным продуктам итальянской кухни - к та- 
ким, как помидоры, базилик - является, для представителей группы, главным признаком, подтверждающим их итальянское происхождение. ${ }^{1}$

На втором месте, среди ответов на данный вопрос, итальянцы Крыма находят в себе черты характера и поведения, которые общепринято считать свойственными коренным итальянцам. Речь идет о повышенной эмоциональности, об обильной и яркой жестикуляции и привычке громко разговаривать. Некоторые представители группы ассоциируют свое ощущение принадлежности к этническим итальянцам с особой любовью к итальянской литературе, культуре и искусству.

Среди тех, кто знает итальянский язык, дополнительным явным признаком итальянского происхождения является особая предрасположенность к изучению языка предков.

Из 10 респондентов, проживающих в Италии, на вопрос о наличии чувства принадлежности к коренным итальянцам, все ответили утвердительно.

\section{Знание итальянского языка среди представителей группы}

Важно отметить, что среди итальянцев Крыма, проживающих в Крыму, само знание итальянского языка не являться фактором, характеризующим группу, как этническую общность, и также не может считаться критерием для определения величины группы.

Проведенный сбор социально-демографических данных показал, что из 101 опрощенных, 64 человека (32 женского и 32 мужского пола) не владеют итальянским языком. 23 представителя группы (17 женщин и 6 мужчин) на языке предков

${ }^{1}$ Некоторые кулинарные традиции, переданные предками, сохраняются по сей день и являются самым мощным фактором, объединяющим потомков итальянских мигрантов в группу.

Совместное приготовление итальянских блюд по бабушкиным рецептам, особенно в случае католических праздников, является для представителей группы причиной встречи.

Главные итальянские блюда у крымских итальянцев - следующие:

- Штуфат - stufato - типичное мясное блюдо северных регионов Италии. Название блюда происходит от древнего способа тушить мясо на печи, путем размещения тлеющих углей на крышке сковороды. Мясо тушится долго, до 8-10 часов при температуре не более 80 градусов. Таким образом, даже нарезки (обычно говяжьи) низкого сорта получаются нежными и сочными. В XIX веке stufato был зимним мясным блюдом, всегда в наличии во всех тавернах Ломбардии.

- Страшнаты - strascinati типичное блюдо южных регионов Италии (в частности, Апулия и Базиликата). Это разновидность макарон домашнего приготовления - небольшие кусочки теста моделируются, точнее тянутся большим пальцем (strascinare с итальянского переводится тянуть) и приобретают форму ушек. Orecchiette (ушки в переводе) это- также типично южная разновидность макарон, похожих на страшнаты, но больше по размерам.

Происхождение strascinati остается загадкой. Согласно местной традиции, их форма напоминает конические крыши традиционных апулийских домов трулли. Другая легенда говорит, что страшнаты впервые изготовила молодая женщина из региона Умбрия.

Другие теории утверждают, что их происхождение связано с традиционной еврейской культурой.

Единственное письменное упоминание о страшнатах находим в произведении неаполитанского писателя XVI в., Джамбаттисты дель Туфо, как о вогнутых макаронах из г. Бари.

- Кавателли - clavatelli традиционная разновидность макарон из региона Молизе, также распространённая на юге Италии.

- Картеддате - carteddate или cartellate - это рождественская сладость круглой формы, из ленты теста. В христианской традиции carteddate напоминают нимб и терновый венец Исуса Христа.

Это блюдо, распространенное на юге Италии, в регионах Апулия, Базиликата и Калабрия с разными названиями, но его происхождение, по всей видимости - греческое. Само название, вероятно, возникло от греческого слова kartallos - (в переводе - конусообразная корзина). 
знают всего лишь несколько слов или выражений. К этой категории принадлежат, в основном, представители старших поколений, у которых остались фрагментарные воспоминания об общении с бабушками и дедушками на родном языке. Переданные из поколения в поколение отрывки речи итальянских предков, дают основания предположить, что их родной язык представлял собой мозаику слов итальянского языка и региональных диалектов происхождения семьи. Среди опрошенных, 9 человек, все женского пола, понимают по-итальянски. Только 5 представителей группы (3 женщин и 2 мужчин) владеют итальянским языком хорошо. Для них, итальянский язык не является родным и был сознательно приобретенным во взрослом возрасте.

Итальянцы Крыма, проживающие в Италии, все владеют итальянским языком. Интересный факт, не поддающийся объяснению, заключается в том, что в отличии от представителей группы старшего поколения, проживающих в Крыму, которые потеряли знакомый им в детстве итальянский язык, все итальянцы Крыма, вернувшие в Италию, сохраняют отличное знание русского языка, вне зависимости от того, сколько лет они провели вдалеке от России. Самым удивительным случаем, является девяностопятилетний дедушка, родившийся в Керчи, вернувшийся в Италию двенадцатилетним подростком и проживающий сегодня в г. Турине. В Россию он больше не возвращался, не имел контактов с русскоязычной средой, но до сих пор в совершенстве владеет русским языком.

\section{Образование и сферы занятости среди представителей группы}

Из 101 испытуемых, проживающих в Крыму, 57 представителей группы (32 женщины и 25 мужчин) имеют среднее образование, 36 - высшее образование (24 женщин и 12 мужчин), 1 представитель женского пола окончил 8 классов, 1 мужского пола - 10 классов, 6 чел. еще учатся (2 женского и 4 мужского пола).

Среди 10 представителей группы, проживающих в Италии, 6 имеют среднее образование (4 женщины и 2 мужчин), 4 высшее образование ((1 женщина и 3 мужчины).

В сфере занятости, самые распространённые профессии среди представителей группы женского пола, проживающих в Крыму - следующие: продавец (8), учитель (4), повар (4), швея (3), бухгалтер (3), медсестра (3), секретарь (2). В Италии находим 2 домохозяйки, 1 домработница, 1 бухгалтер и 1 юрист.

Среди наиболее часто встречающих профессий у представителей группы мужского пола, проживающих в Крыму, 5 человек работают на морских суднах, 4 строителя, 3 водителя и 3 повара.

В Италии 1 портовый работник, 1 капитан, 1 матрос, 1 юрист и 1 банковский работник.

\section{Метисация в группе}

На сегодняшний день, степень метисации, в процентном эквиваленте, составляет 100\% среди представителей группы женского и мужского пола.

Из 42 представителей группы мужского пола, проживающих в Крыму, 24 состоят в браке с русскими, 1 с белорусской. 17 мужчин не состоят в браке.

Из 5 представителей группы мужского пола, проживающих в Италии, 1 состоял в браке с русской, у 4 мужчин жены нет. 
Из 59 представителей группы женского пола, проживающих в Крыму, 33 состоят в браке с русскими, 11 с украинцами, 1 с узбеком, 1 с караимом. 13 женщин не состоят в браке.

Из 5 представителей группы женского пола, проживающих в Италии, 1 состоит в браке с русским. 4 женщины не состоят в браке (Рис. 4).

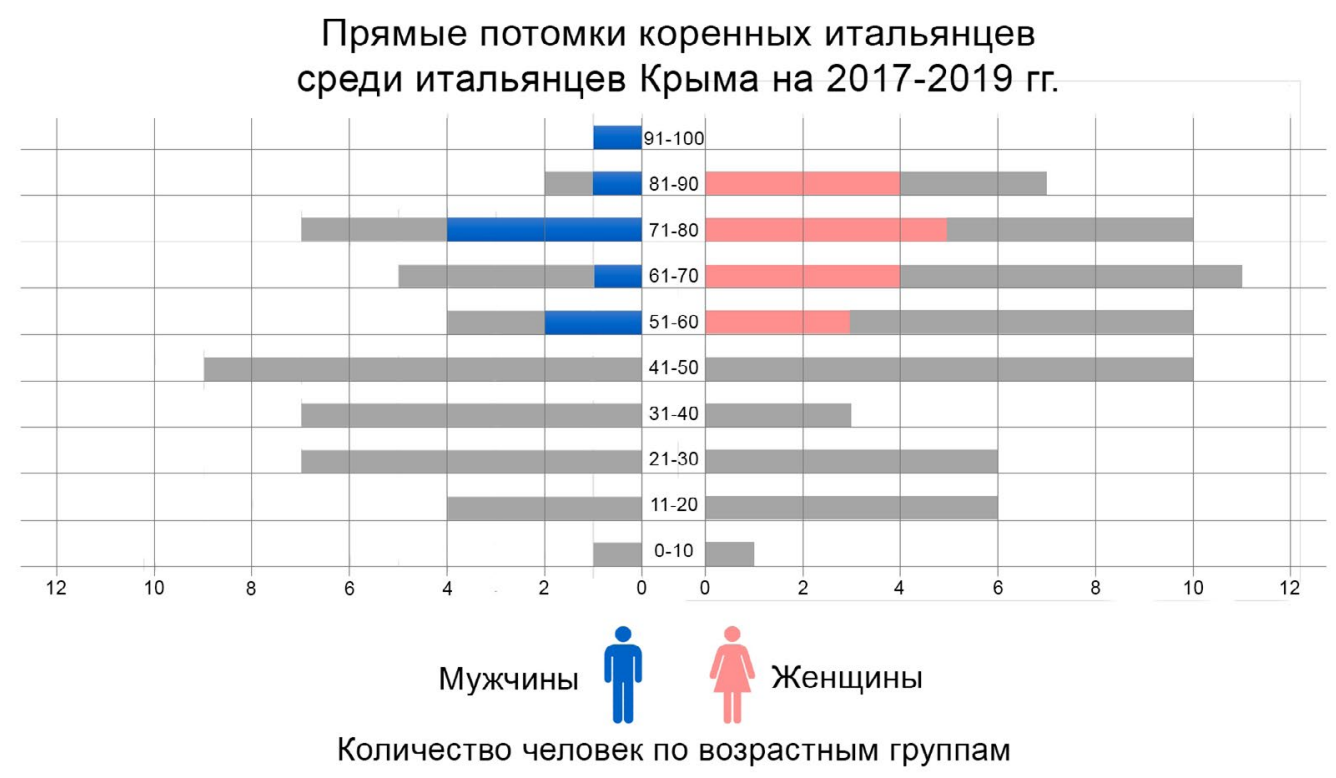

Рис. 4. Прямые потомки коренных итальянщев

среди итальяниев Крыма на 2017-2019 годы.

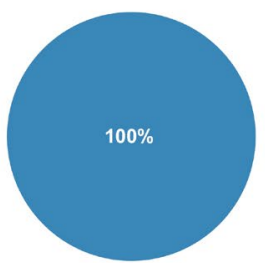

I поколение

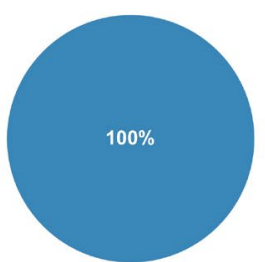

Метисация итальянцев Крыма в пяти поколениях

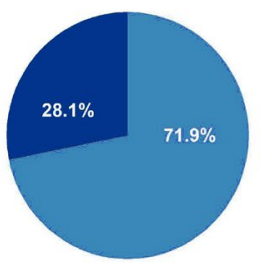

II поколение

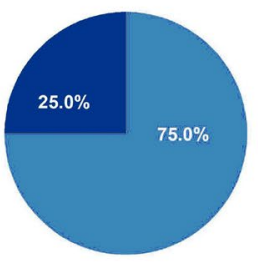

Рис. 5. Метисация итальянцеев Крыма в пяти поколениях.

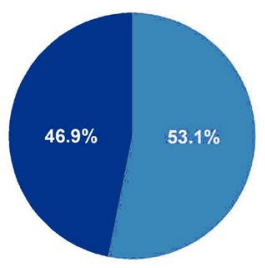

III поколение

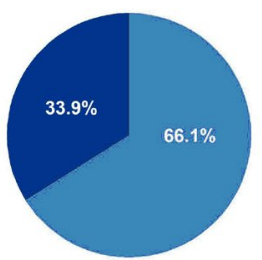

\% метисации

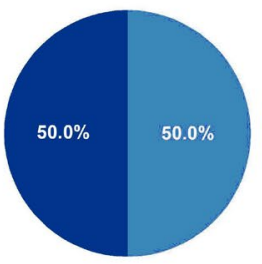

IV поколение
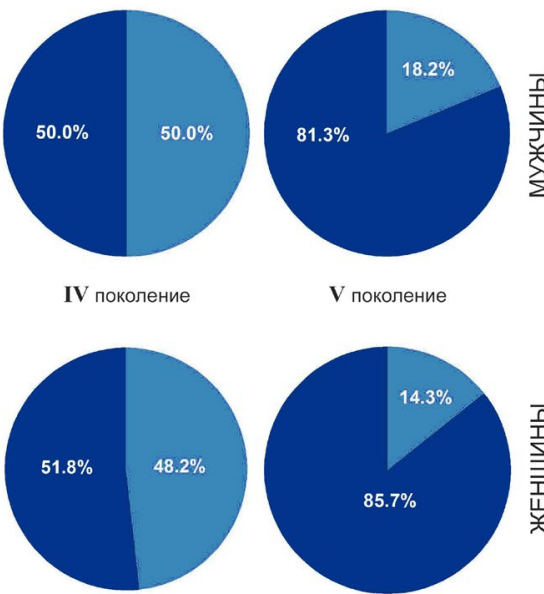

V поколение

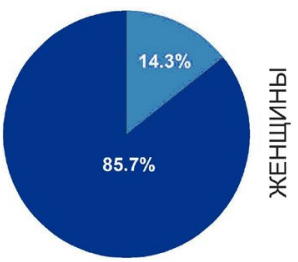


Количество смешанных браков и, последовательно, степень метисации постепенно уменьшается в предыдущих четырех поколениях и выглядит следующим образом. Во втором поколении, метисация сокращается до 71,9\% и 75\% среди представителей женского и мужского пола, в третьем поколении - до $53.1 \%$ и $66.1 \%$, в четвертом поколении - до $50.0 \%$ и $48.2 \%$ и в пятом поколении до $18.2 \%$ и $14.3 \%$ (рис. 5).

\section{Процессы воспроизводства в семьях потомков итальянских мигрантов}

Для антропологии представляет несомненный интерес анализ процессов биологической адаптации итальянских групп к новым экологическим и социальным условиям Крыма и формирование поколений их потомков в условиях иноэтнического окружения. А для генетиков важен аспект, связанный с наибольшим вкладом мигрантов, особенно представителей из географически отдаленных этнических групп, в повышение генетического разнообразия популяций. В генетическом смысле происходит миграция генов. И приток новых генов в популяцию можно сравнить с возникновением новых мутаций (Курбатова и др. 2016: 831-851). Поэтому изучение структуры браков и состояния здоровья родителей может привнести новую информацию необходимую для оценки физического и психического статуса поколения детей (Бычковская и др. 2018; Спищылна 2018: 395). В этом отношении особенности воспроизводства численности итальянской диаспоры очень важны, поскольку репродукция является универсальным индикатором, который чутко реагирует на все происходящие изменения.

Результат индивидуальной плодовитости можно оценить только в группе женщин, вышедших из репродуктивного возраста. Таких среди потомков итальянских переселенцев, рожденных в Керчи, оказалось 30 человек, причем две из них ныне проживают в разных городах Италии.

В соответствии с законом о защите персональных данных, все сведения респонденток были деперсонифицированы. С добровольного согласия у женщин старше 45 лет собрана биодемографическая информация о возрасте начала menarche, климакса, беременностях, родах, выкидышах, медицинских абортах, мертворождениях и причинах смерти детей. Учитывались также данные о возрасте, национальности мужа и его родителей. Всего заполнено 30 индивидуальных карт акушерского анамнеза семьи. Все семьи потомков итальянских мигрантов оказались смешанными, не было ни одного однонационального брака. Результаты обследования репродуктивных процессов в сборной группе из 30 женщин, завершивших индивидуальную репродукцию, показали, что только $38,26 \%$ всех беременностей закончились родами, искусственным прерыванием завершилось 46,09\% беременностей, количество ранних и поздних спонтанных абортов, а также внематочных беременностей составило 10,43\%, 13,33\% женщин бездетны. В среднем на 1 женщину пострепродуктивного возраста приходится $3,8333 \pm 0,1076$ беременности, $1,5000 \pm 0,0459$ родов и $1,7667 \pm 0,0887$ абортов. К сожалению, мы не имеем данных по предшествующему поколению родителей наших респондентов. Но опосредованно, ориентируясь на сведения о количестве братьев и сестер, получаем, что в среднем матери наших обследованных женщин имели $1,8111 \pm$ 0,91013 родов, что также меньше 2,13 необходимой для простого воспроизводства численности в популяции. Таким образом, выявлен суженный тип воспроизводства, несколько слабее выраженный в предшествующем поколении. 
Дети из межнациональных семей отличаются повышенной степенью индивидуальной гетерозиготности, которая способствует возрастанию показателей общей гетерозиготности популяций. В этом плане очень интересны результаты работ профессора Е.У. Куандыкова с соавторами, исследовавших показатели репродуктивной функции женщин г. Алма-Ата. Они проанализировали исходы беременностей в браках казахов, русских, уйгуров, немцев, корейцев, татар, украинцев, а также в межэтнических и межрасовых браках. Наименьшая частота ранних спонтанных абортов наблюдалась в однонациональных браках $(4,19 \%)$, выше была в межнациональных $(6,25 \%)$ и самая высокая - в межрасовых (7.22 \%). Аналогичная ситуация наблюдалась и в частоте поздних спонтанных абортов. Результаты, полученные в межэтнических браках нашего исследования по ранним и поздним спонтанным абортам и внематочным беременностям составившим $10,43 \%$ и $13,33 \%$ бездетным женщинам, также могут являться следствием увеличения генетического полиморфизма и изменения генетического гомеостаза.

Далее с применением классического метода Дж. Кроу были вычислены коэффициенты максимально возможного потенциального отбора $\mathrm{I}_{\mathrm{T}}$ и составляющие компоненты дифференциальной плодовитости $\mathrm{I}_{\mathrm{f}}$ и смертности $\mathrm{I}_{\mathrm{m}}$ (Crow 1958: 1-13). Количественно определена сила социальной регуляции репродуктивных процессов в популяциях (Спииьна 2006: 212; Бодрошева и др. 2018: 118-128). Предшествующее поколение женщин имеет в среднем невысокое значение $\mathrm{X}_{\mathrm{s}}=1.4667$ живых детей, приходящихся на одну женщину с вариансой $\mathrm{V}_{\mathrm{f}}=0.8017$. В выборке женщин пострепродуктивного возраста в объединенной группе достаточно благоприятные показатели всех исследуемых параметров репродукции выявлены по первому варианту расчета, при котором в анализ не включались аборты (1). Наблюдается более высокая пропорция детей, доживших до репродуктивного возраста $\left(\mathrm{P}_{\mathrm{s}}=0.7587\right)$, компоненты дифференциальной смертности $\left(\mathrm{I}_{\mathrm{m}}=0.3180\right)$, компоненты дифференциальной плодовитости $\left(\mathrm{I}_{\mathrm{f}}=0.3563\right)$, и особенно значения тотального индекса отбора $\left(\mathrm{I}_{\mathrm{T}}=0.7876\right)$. Результаты расчета индексов потенциального отбора и его компонентов с включением в анализ числа абортов (2 вариант) показали выраженные различия в исследуемых параметрах процессов воспроизводства. Пропорция детей, доживших до репродуктивного возраста, снизилась почти в 2 раза $\left(\mathrm{P}_{\mathrm{s}}=0,3964\right)$, компонента дифференциальной смертности возросла до $\mathrm{I}_{\mathrm{m}}=1,5227$, величина индекса тотального отбора резко увеличилась до 2,4215. Разница между вычисленными разными способами величин тотальных индексов $\mathrm{I}_{\mathrm{T} 2}=1,6339$ в группе соответствует силе, с которой регулируется численность детей в семьях, и соответствует вкладу социальной компоненты в величину коэффициента потенциального отбора.

Анализ параметров воспроизводства в возрастных когортах женщин завершивших индивидуальную репродукцию, выявил следующее.

1. Снижение темпа плодовитости, о чем свидетельствует пониженное среднее число беременностей, приходящееся на 1 женщину.

2. В семьях суженный тип воспроизводства - среднее число детей существенно ниже $\mathrm{X}_{\mathrm{s}}=2.13$, необходимого для простого воспроизводства численности в поколениях.

3. Дисперсия ниже самого среднего значения, что свидетельствует о жестком регулируемом характере воспроизводства в семьях. 
4. Основной вклад в пренатальные потери вносят медицинские аборты $(46,09 \%)$, и спонтанные аборты (10,43\%).

5. Выявлен урбанизированный, регулируемый характер воспроизводства суженного типа, сходный с особенностями репродукции в городах большой численности.

\section{Заключение}

Таким образом, в настоящем сообщении по результатам проведенного исследования на основании документов и свидетельств из российских и итальянских архивов представлена воссозданная география и хронология трех основных миграционных потоков итальянцев в Черноморско-Азовский регион России.

По архивным материалам была реконструирована сложная история формирования Керченской диаспоры итальянцев.

Исследование биодемографических аспектов адаптации Керченской диаспоры итальянцев показало, что уровень метисации современных потомков достигает $100 \%$. Анализ параметров воспроизводства в возрастных когортах женщин, завершивших индивидуальную репродукцию, выявил демографический переход от многодетности в семьях к малодетности, от расширенного типа воспроизводства и простого к суженному. Выявлен урбанизированный, регулируемый характер воспроизводства суженного типа, сходный с особенностями репродукции в городах большой численности.

\section{Научная литература}

Бодрошева Н.Г., Балинова Н.В., Спищына Н.Х. Сравнительный антропогенетический анализ процессов воспроизводства популяции Горно-Алтайска // Вестник Московского университета. Серия XXIII. Антропология, 2018. № 3/2018. С.118-128.

Бычковская Л.С., Балинова Н.В., Спицына Н.Х., Спицын В.А. Полиморфизм генов, экспрессирующихся в грудном молоке, в связи с соматотипом новорожденных и репродуктивной функцией женщин // Вестник Московского университета. Серия 23: Антропология, 2018. № 1. С. 43-49.

Дзини С., Хохлов Н.В. Материалы ранее неопубликованных демографических опросов, проведенных среди итальянцев Крыма в ходе экспедицией в Крыму 2016-2019 гг.

Джаккетти-Бойко Итальянцы Крыма. История и Судьбы. Симферополь: «Бизнес- Информ», 2016. С. 16.

Законодательство Российской Федерации. Федеральный закон «Об актах гражданского состояния〉 от 15.11.1997. № 143-Ф3, ст.23 (ред. От 01.10.2019) - Свидетельство о рождении. https://fzrf.su/zakon/ob-aktah-grazhdanskogo-sostoyaniya-143-fz/st- 23.php.

Итоги переписи населения в Крымском Федеральном Округе - Федеральная служба государственной статистики. Официальное издание. ИИЦ «Статистика России». Москва. 2015 С.108, 118, 119, 122, 129, 135-141.

Курбатова О.Л., Янковский Н.К. Миграция - основной фактор популяционной динамики городского населения России // Генетика, 2016. Т. 52, № 7. С. 831-851.

Писаревский Г.Г. Избранные произведения по истории иностранной колонизации. Москва: ЗАО «МСНК-пресс», 2011. С. 90-106, 117.

Спиџына Н.X. Демографический переход в России. Антропогенетический анализ. Москва: Наука, 2006. С. 212.

Спицына Н.Х. Самородок с Полюса холода. М.: ИТРК, 2018. 
Указ Президента Российской Федерации - О мерах по реабилитации армянского, болгар ского, греческого, итальянского, крымско-татарского и немецкого народов и го сударственной поддержке их возрождения и развития (В редакции Указа Прези дента Российской Федерации от 12.09.2015 г. N 458). http://kremlin.ru/acts/bank/.

3835628.05 .2019

Crow J.F. Some possibilities for measuring selection intensities in man // Human Biol., 1958. № 30. P. 1-13.

Gardini S., Sinigaglia R., Rebora G. I Contatti Commerciali tra Genova e il Mar Nero nella Metà del XIX Secolo. Genova: Università degli Studi di Genova. Facoltà di Lettere e Filosofia. Corso di Laurea in Storia, 2003-2004.

\section{References}

Bodrosheva, N.G., N.V. Balinova, and N.H. Spitsyna. 2018. Sravnitel'nyj antropogeneticheskij analiz processov vosproizvodstva populyacii Gorno-Altajska [A comparative anthropogenetic analysis of the processes of reproduction of the population of Gorno-Altaisk]. Vestnik Moskovskogo universiteta. Seriya 23. Antropologiya 3: 118-128.

Bychkovskaya, L.S., N.V. Balinova, N.H. Spitsyna, V.A. Spitsyn. 2018. Polimorfizm genov, ekspressiruyushchihsya $\mathrm{v}$ grudnom moloke, $\mathrm{v}$ svyazi s somatotipom novorozhdennyh $\mathrm{i}$ reproduktivnoj funkciej zhenshchin [The polymorphism of genes expressed in breast milk in connection with the somatotype of the newborns and the reproductive function of the women]. Vestnik Moskovskogo universiteta. Seriya 23: Antropologiya 1: 43-49.

Crow, J.F. 1958. Some possibilities for measuring selection intensities in man // Human

Biol. 30: 1-13.

Gardini, S., R. Sinigaglia, G. Rebora. 2003-2004. I Contatti Commerciali tra Genova e il Mar Nero nella Metà del XIX Secolo. [The commercial relationships between Genoa and the Black Sea in the middle of the 19th century]. Genova: Università degli Studi di Genova. Facoltà di Lettere e Filosofia. Corso di Laurea in Storia.

Giacchetti-Bojko, Dzh.E. 2016. Ital'yantsy Kryma. Istoriya i sud'by. [The Italians of Crimea. Their History and stories]. Simferopol': Biznes-Inform: 16.

Itogi perepisi naseleniya v Krymskom Federal'nom Okruge. 2015 [Census Results led in the Crimean Federal District - Federal State Statistics Service Official publication. IIC "Statistics of Russia"]. IIC «Statistika Rossii», 108, 118, 119, 122, 129, 135-141. Moscow: Federal'naya sluzhba gosudarstvennoj statistiki Oficial'noe izdanie.

Kurbatova, O.L., and N.K. YAnkovskij. 2016. Migraciya - osnovnoj faktor populyacionnoj dinamiki gorodskogo naseleniya Rossii [The migration as the main factor in the population dynamics of the urban population of Russia]. Genetika 52 (7): 831-851.

Pisarevskij, G.G. 2011. Izbrannye proizvedeniya po istorii inostrannoj kolonizatsii v Rossii. [Selected works on the history of foreign colonization], 90-106, 117. Moscow: ZAO «MSNKpress»».

Spitsyna, N.Kh. 2006. Demografichesky perekhod v Rossii. [The demographic transition in Russia. An anthropogenetic analysis]. Antropogenetichesky analiz. Moscow: Nauka.

Spitsyna, N.H. 2018. Samorodoks Polyusa holoda. [A nugget from the Pole of Cold]. Moscow: ITRK.

Zini, S., N.V. Khokhlov. 2016-2019. Materialy ranee neopublikovannikh demograficheskikh oprosov, provedennikh sredi ital'yancev Kryma v khode ekspediciej v Krymu [Materials of previously unpublished demographic surveys conducted among the Italians of Crimea, during several expedition to Crimea and Italy, led in 2016-2019]. 
Zini, Stefania, Spitsyna, Nailya K., Khokhlov, Nikita $V$.

\section{Biodemographical aspects of adaptation of the Italian diaspora in Kerch}

After a brief historical introduction about the origins of the modern diaspora of the "Crimean Italians", the article describes the results of a comprehensive social and biodemographic analysis conducted among the modern representatives of the group, based on a questionnaire designed for this study.

The data collected during several expeditions to Crimea and Italy (2016-2019) are being published for the first time. The modern Italians of Crimea are the descendants of Italian migrants who arrived from the Apennine Peninsula in the Black Sea and Sea of Azov regions - to the Crimean peninsula in particular - with different migration flows, which took place among the end of the 18th-the beginning of the 20th cc.

Key words: demography, migration flows, migrants, historical essay, field research, Crimean Italians, Kerch, Apennine Peninsula, Italy, Crimea 


\title{
АНТРОПОЛОГИЧЕСКАЯ МОЗАИКА
}

УДК $39+355 / 359$

DOI: $10.33876 / 2311-0546 / 2020-50-2 / 193-205$

(C) Н.А. Белова

\section{«РЫЦАРИ БЕЗ СТРАХА»: ВОСПОМИНАНИЯ УЧИТЕЛЕЙ - УЧАСТНИКОВ ВЕЛИКОЙ ОТЕЧЕСТВЕННОЙ ВОЙНЫ*}

\begin{abstract}
В статье на основании эго-документов рассказываются фронтовые истории учителей, принимавших участие в Великой Отечественной войне. Эти истории были записаны ещуе к 20-летию победы, но иензура советского времени не допустила сборник к печати. Мемуары, сохранившиеся в Государственном архиве Костромской области (ГАКО), свидетельствуют об ужасных событиях того времени, когда выражение «мирное небо» становится символичныли. Важность этих эго-документов заключается в том, что они являются прямым свидетельством тех событий, которые произошли 75 лет назад. В каждой российской семье есть герои-участники этого исторического события, кто-то из них сражался, а кто-то работал в тылу и нама задача рассказывать об этих подвигах, чтобы они не предавались забвению. Именно поэтому мы подготовили статью, в которой советские учителя вспоминают о жизни, подвигах, быте на фронтах Великой Отечественной войны. Мы попытались рассказать об основных аспектах того трудного периода, о том как людям приходилось выживать и выходить из душевного кризиса после пережитых потрясений.
\end{abstract}

Ключевые слова: эго-документы, Великая Отечественная война, жизнь, фронт, подвиги, учителя

О Великой Отечественной войне 1941-1945 гг. написано немало работ, опубликованы мемуары, воспоминания и другие эго-документы как первых государственных лиц, так и простых людей, которые описывают события того времени. Но помнить и публиковать новые свидетельства о событиях того времени - наш первостепенный долг. Чтобы мы умели ценить и радоваться каждому мирному дню, чтобы не забывали, что счастье рядом и оно в мелочах, важно понимать цену военных побед! Наша жизнь стала стабильной, хорошей и спокойной. Большинство из нас сейчас могут съездить в другую страну, позволить себе отдых на море или в самом крайнем случае поехать отдыхать на дачу. А ведь всего 75 лет назад наши соотечественники

Белова Наталья Андреевна - к.и.н., научный сотрудник ЦЭПИ Института этнологии и антропологии РАН (Москва, Ленинский пр. 32-А). Эл. почта: belovanatalia1986@gmail.ru. Belova, Natalya A. - Institute of Ethnology and Anthropology, RAS (Moscow, Leninsky Prospect 32-A). E-mail: belovanatalia1986@gmail.ru.

* Публикуется в соответствии с планом научно-исследовательских работ Института этнологии и антропологии РАН 